\title{
The Sustainable-based Impacts of Built Environmental Influencing Factors on Price-rent Ratio: A Case Study in Guangzhou
}

\author{
${ }^{1}$ Wenjing LI, School of Architecture, State Key Laboratory of Subtropical Building Science, South China \\ University of Technology, Guangzhou, Guangdong Province, China \\ ${ }^{2}$ Dawei XIAO, School of Architecture, State Key Laboratory of Subtropical Building Science, South China \\ University of Technology, Guangzhou, Guangdong Province, China
}

\begin{abstract}
As an indicator of the real estate market, a reasonable housing price-rent ratio will promote the sustainable development of the real estate market, thereby promoting the sustainable development of the city. Sustainable urban construction will also promote the rationalization of the housing price-rent ratio in turn, which will have a positive impact on the real estate market. Exploring and comparing factors affecting the price-rent ratio is important for urban sustainability. Using house purchase transaction and rent transaction data in 2018 in Guangzhou, China, this paper analyzed the spatial distribution pattern of price-rent ratio acquired by the Inverse Distance Weighted interpolation method and a quantile regression model was employed to quantify the impacts of built environmental factors on price-rent ratio. Moreover, this paper further discussed the bidirectional influence mechanism of urban sustainability construction and housing price-price ratio. Results showed that the price-rent ratio has a dispersed distribution with multiple centers. The highs lie in the suburbs or handed-over areas between newly-built and old built-up parts of the city. The price-rent ratio is mainly influenced by fife services such as leisure and entertainment, shopping centers, sports facility, education resources such as university and school, green infrastructures such as green space and waterfront. Daily Life services contribute more to low-level price-rent ratio and leisure, entertainment and cultural facility contributes more to high-level price-rent ratio. Sustainable urban development as well as real estate development should pay attention to the construction of green infrastructure, public transit, commercial services, medical service, spiritual services and educational services. This study will lay a solid foundation for formulating real estate policies within the built environment and helps integrating real estate markets into sustainable urban development activities to achieve urban sustainability.
\end{abstract}

\section{Keywords}

Price-rent ratio, real estates, urban economy, urban sustainability

\section{Introduction}

Sustainable cities meet the development needs of urban residents without placing unsustainable demands on local or global resources and systems, thereby becoming more socially, environmentally and financially sustainable. The pillars for achieving sustainability of cities are social development, economic development, environmental management, urban governance, and sustainable finance (Jiboye, 2011). As an influential sector in the national economy, real estate and the urban economy play an essential role in 
sustainable economic growth. Sustainable development of a healthy real estate market contributes to improve citizens' quality of life and achieve sustainable urban management.

Representing the relationship between housing price and rent, the price-rent ratio is an indicator of the real estate market (Zhai et al., 2018). The housing price-rent ratio and urban sustainability are mutually reinforcing. A reasonable housing price-rent ratio will promote the sustainability of the real estate market, thereby promoting the sustainable development of the city; in turn, sustainable urban construction will also promote the rationalization of the housing price-rent ratio, which will have a positive impact on the real estate market. The impact is especially reflected in the construction of urban infrastructure. Therefore, exploring and comparing factors influencing the price-rent ratio are important for urban sustainability.

With reference to the housing price-rent ratio, a myriad of papers have focused on the macrofactors of society or economy that influence the price-rent ratio. However, there are few studies focus on investigating the micro-level factors of the built environment that influence the price-rent ratio. Some studies have been conducted to uncover the built environment factors that affect the housing price or housing rent separately. But the influences of the built environment on the price-rent ratio have not been studied fully. Such kind of vacancy needs to be filled.

However, operating this kind of study could be difficult. Firstly, without a series of housing prices and rent records, as well as urban infrastructure data, the analysis could be very hard and unreliable. Secondly, proper a suitable model to describe the relationship between urban infrastructure factors and price-rent ratio, then extract the most influential factors, is hard to design. Many aspects should be put into consideration like multicollinearity of factors and the reliability of the model. Finally, the analysis should be operated from various aspects and find out how urban sustainable construction influences housing price-rent ratio.

Utilizing massive housing price and rent records in Guangzhou area, this paper proposed an analysis of the micro-level factors of the built environment that influence the price-rent ratio and explored the bidirectional influence mechanism of urban sustainability construction and housing price-price ratio. Firstly, this paper utilized the housing purchase data and housing rent data in November 2018 in Guangzhou, and combined Inverse distance weighted (IDW) interpolation methods to estimate the pricerent ratio. Secondly, the paper employed the quantile regression model to extract the most influential factors. Finally, this paper discussed the spatial distribution pattern of price-rent ratio and the influencing mechanisms of urban sustainability construction and price-rent ratio. The result of the paper sheds light on real estate policies and helps integrating real estate markets into sustainable urban development activities to achieve urban sustainability.

\section{Literature Review}

The price-rent ratio is an important issue in real estate study. The price-rent ratio is considered as a valid indicator in reflecting the health of the real estate market (Xie and Liu, 2004, Zhai et al., 2018). Sommer et al. (2010) discovered that low interest rates, relaxed lending standards, and high incomes caused mostly the growth of price-rent ratio in the US as well as rapidly rising house prices, inactive rents, growing homeownership, and increasing household indebtedness. Cronin and McQuinn (2016) indicated that regulatory limitations can increase demand for rental accommodation greatly and higher rents for a given house price. Kishor and Morley (2015) found that the variation in the expected housing return will lead to the variation in the present-value component of the price-rent ratio. These studies focused on this topic from the perspective of economic and regulatory factors, which are macro-level factors. The influence of these factors on the price-rent ratio is obvious and easy to understand. 
On the other hand, micro-level factors in the urban area also impact the housing price and rent to a deep extent. In most relevant studies, micro-level factors include access to the live services catering and shopping centers, accessibility to green spaces and open spaces nearest to the properties, accessibility to amenities such as parks, seascapes, waterways and landscapes, environments such as noise and air quality condition and so on (Cohen and Coughlin, 2008, Hui et al., 2007, Lee and Li, 2009). Some researchers have studied the micro-level factors influencing housing prices or housing rent separately. From the perspective of house pricing, Visser et al. (2008) discovered the attributes of the residential environment that affect the regional house price. woodland and water, social status and ethnicity as well as accessibility to employment can be important factors. When it comes to housing rent, Nakagawa et al. (2007) found out that utility facilities, industrial districts and sporting facilities negatively influence the house renting, while medical, commercial, cultural, accommodation facilities, education have a positive effect. These studies were mainly concerned about the issue of house prices or housing price, while fewer of them researched on the price-rent ratio. As previously elaborated, they mainly focused on the economic and political factors. This kind of gap needs to be filled. Moreover, the impact factors in different cities are different, so it is necessary to carry out empirical research in different cities.

This paper mainly contributes in the following aspects: (1) this paper collected the housing price and housing rent data from a Chinese authoritative website of housing. Therefore, the sample is reliable and large enough to accurately describe the property value and price-rent ratio (2) as the housing price and housing rent in Guangzhou, China has never been studied before, this study enriches the study area and empirical city examples of related research (3) we discussed the spatial distribution pattern and influencing factors of price-rent ratio, which are seldom discussed previously. (4) we discussed the influencing mechanisms of urban sustainability construction and price-rent ratio.

\section{Dataset and variables}

\subsection{Case selection}

In this paper, Guangzhou, China was taken as the case study for the analysis. Guangzhou is the capital city of Guangdong province and one of the largest cities in south China. According to the statistical data from the National Bureau of Statistics of China, in 2018, the Gross Domestic Product (GDP) for Guangzhou is the fourth among all the cities in China. Up to 2018, the resident population of Guangzhou is 14.90 million and the population growth rate is $13.0 \%$. The urbanization rate is $86.38 \%$ (Guangzhou statistical yearbook 2019). Real estate market of Guangzhou boom under this high urbanization rate and population growth.

In this study, we select the main urban area Tianhe, Yuexiu, Baiyun, Haizhu, Liwan, Huangpu, Fanyu as the research area. These cover the area of $2345.74 \mathrm{~km} 2$ and account for around $31.5 \%$ of the administrative region of Guangzhou.

\subsection{Dataset}

\subsubsection{Housing price and rent}

The dataset of housing prices and rent of Guangzhou was collected from Lianjia (https://gz.lianjia.com/). As China's largest real estate brokerage platform, Lianjia provides detailed transaction information of new houses, second-hand houses, and rental houses in most cities of China. The accessible information of housing prices and housing rents on Lianjia is updated in real-time; therefore, it keeps up well with the market dynamics. In this study, we utilized second-hand houses prices and rental houses prices to calculate the price-rent ratio, because the newly-built houses are 
mainly located in suburbs and relatively few downtowns, which causes a biased error potentially. A dataset recording detailed information of on-sale second-hand houses and rental houses listed on Lianjia during the week ending 11 November 2018 was collected in this study. The prices and rents of this period are stable, for it is not the graduation season or entry season. The dataset contains detailed information of 27816 housing price records and 12204 housing rent records. For each record, its price/rent, latitude and longitude are included.

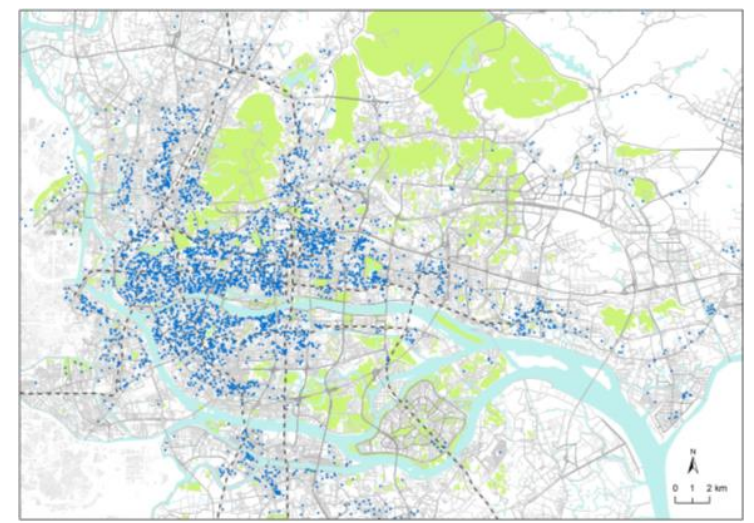

(a)

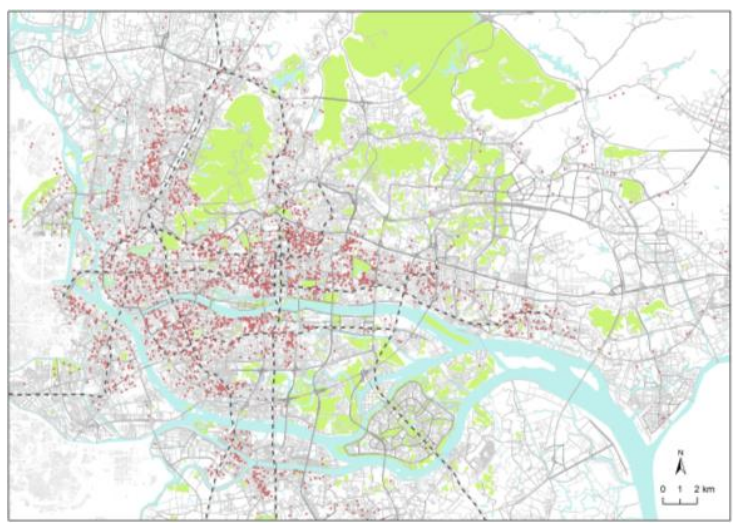

(b)

Figure 1. Points of housing price (a) and housing rent (b)

\subsubsection{Built environment data}

The dataset of the built environment is also obtained from AutoNavi (https://www.amap.com/) and it contains 3 types: point, line, and polygon. Point data includes the bus station and the metro station. Line data includes roads. Polygon data includes the buildings, green space, water system.

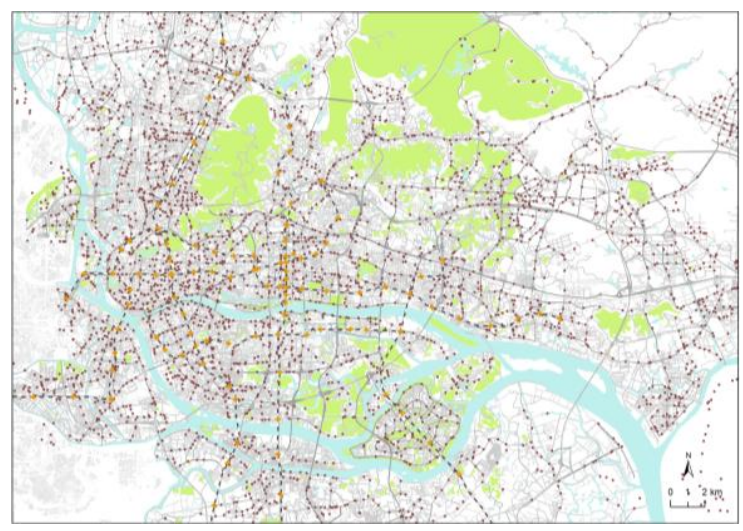

Figure 2. The dataset of the built environment

\subsubsection{Points of Interest}

The dataset of points of interest (POIs) is obtained from AutoNavi (https://www.amap.com/) and they are separated into 16 categories: catering, life service, leisure and entertainment, sport facility, shopping, hospital, university, school, cultural facility, enterprise, governmental agency, financial institution, industrial park, science and cultural institution, cemetery, tourist attractions. There are 230510 POI totally in this study. 


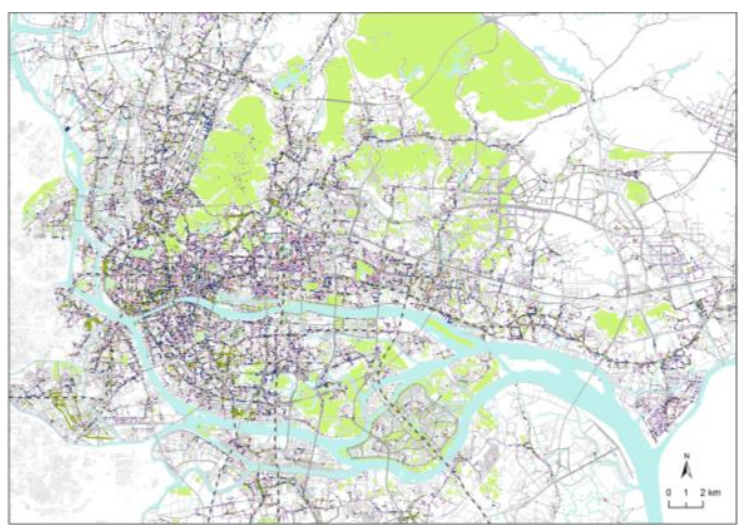

Figure 3. Points of interest

\subsection{Variables}

The definitions of variables are listed in Table 1 . In this article, the threshold value of the walking area radius used in density calculation is quantified as $500 \mathrm{~km}$, which is the product of the maximum tolerable walking time (15 $\mathrm{min}$ ) and the average walking speed (1m/s) of adults (Yang et al., 2018).

Table 1. Variable definitions and descriptions.

\begin{tabular}{|c|c|c|}
\hline Categories & Variables & Description \\
\hline \multirow{5}{*}{ Life services } & Catering & Number of catering within the walking area of sampling points \\
\hline & $\begin{array}{l}\text { Leisure \& } \\
\text { entertainment }\end{array}$ & $\begin{array}{l}\text { Number of leisure and entertainment centers within the walking area of } \\
\text { sampling points }\end{array}$ \\
\hline & Shopping & Number of shopping centers within the walking area of sampling points \\
\hline & Hospital & Number of hospitals within the walking area of sampling points \\
\hline & University & Number of universities within the walking area of sampling points \\
\hline \multirow{4}{*}{$\begin{array}{l}\text { Job } \\
\text { opportunities }\end{array}$} & financial institution & Number of financial institutions within the walking area of sampling points \\
\hline & Government & Number of governments within the walking area of sampling points \\
\hline & $\begin{array}{l}\text { Science \& culture } \\
\text { Institution }\end{array}$ & $\begin{array}{c}\text { Number of science and culture institutions within the walking area of sampling } \\
\text { points }\end{array}$ \\
\hline & industrial park & Number of industrial parks within the walking area of sampling points \\
\hline \multirow{2}{*}{$\begin{array}{l}\text { Green } \\
\text { infrastructure }\end{array}$} & Greenspace & Euclidean distance to the nearest green space \\
\hline & Waterfront & Euclidean distance to the nearest waterfront \\
\hline \multirow{2}{*}{$\begin{array}{l}\text { Development } \\
\text { Density }\end{array}$} & coverage area & The total coverage area of buildings within the walking area of sampling points \\
\hline & building area & Total building area of buildings within the walking area of sampling points \\
\hline other & tourist attraction & Number of tourist attractions within the walking area of sampling points \\
\hline
\end{tabular}




\section{Methodology}

\subsection{Problem Description and Analytical Framework}

The main target of this paper is to uncover the spatial distribution pattern of price-rent ratio and extract the most influential factors of price-rent ratio, then give an analysis of the influence mechanism of the price-rent ratio and factors. We need to solve three problems from our dataset:

(1) Estimate the overall price-rent ration distribution from individual housing price and housing rent data

(2) Extract the most influential factors from the data: variables of the built environment have severe multicollinearity, which may lead to a distortion of results or difficulty to estimate the model accurately. Choose a suitable model is a critical problem.

(3) the mechanism of the price-rent ratio and influencing factors need to discuss carefully.

To solve the challenges and problems described above, we chose the framework shown in Figure 4.

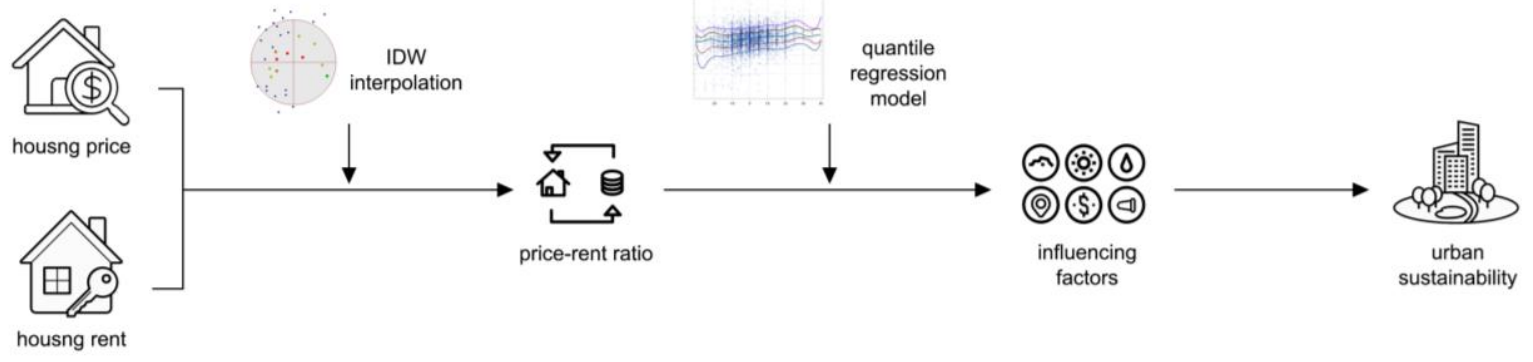

Figure 4. The framework used in this paper

\subsection{Inverse distance weighted (IDW) interpolation}

To acquire data that are not available at their locations and observe the general trend, we utilized inverse distance weighted (IDW) interpolation to evaluate the spatial distributions of housing price and housing rent, from which we can calculate the price-rent ratio of each cell of the total research area. IDW interpolation is a technique that achieves to estimate the cell values of spatially distributed variables utilizing a linearly weighted combination of data points with known values. The weight is a function of inverse distance and it decreases as distance increases from the interpolated points. This method assumes that the measured values that are closer to the prediction cell have more impacts on the predicted value than those farther away. As IDW interpolation is relatively efficient and easy to compute(Abedini et al., 2016), this method has been widely used in the distribution research such as housing price (Yu et al., 2007, Li et al., 2017), land price (Junming, 2007), urban attraction potential (Abedini et al., 2016), air quality (Anselin and Le Gallo, 2006), water quality (Liu et al., 2017), bathymetric measurements (Diaconu et al., 2019), etc.

The housing price and housing rent show the characteristics of spatial gathering. Housing price and housing rent that are close to one another are more alike than those farther away, as the locations get farther away, the measured values will have little relationship with the value of the prediction location. Therefore, in this case, IDW interpolation is suitable for us to evaluate the spatial distribution pattern of housing prices and housing rent on large scale, thus calculate the price-rent ratio and obtain the spatial distributions of price-rent ratio. 


\subsection{Price-rent ratio computation}

The costs of owning a house relative to the cost of renting a house can be estimated utilizing the median house value and the median gross rent. In this study, the price-rent ratio of each cell was calculated approximately as follow:

$R=\frac{P}{Z} \times 100 \%$

Where $\mathrm{R}$ refers to the price-rent ratio. $\mathrm{P}$ refers to the housing price and $\mathrm{Z}$ refers to the housing rent.

Housing price-rent ratio can present the relationship between housing prices and housing rent. The price-to-rent ratio indicates the relative affordability of purchasing and renting a house in the real estate market. If the housing price-rent ratio is low, which means the cost of owning a house exceeds that of renting, more will be renting, and housing prices will decrease (and/or rents will increase). The renting market will be more active than the buying market. Conversely, if the housing price-rent ratio is high, which means that the cost of ownership is lower than that of renting, more will be buying, and housing prices will increase (and/or rents will fall). The buying market will be more active than the renting market in this situation. If prices are too high, there will be a real estate bubble.

\subsection{Quantile regression}

Quantile regression is a statistical method to calculate and infer conditional quantiles. Different from the traditional ordinary least squares (OLS) linear model, the quantile regression estimates the effects along with the distribution of the dependent variables instead of the average effects. Instead of inferring relationships of the variables based on conditional central tendency, quantile regression can be utilized to estimate models for different conditional quantiles of the conditional distribution.

The quantile regression is described by the following equation:

$\mathrm{y}_{\mathrm{i}}=\mathrm{x}_{\mathrm{i}}^{I} \beta_{\mathrm{q}}+\mathrm{e}_{\mathrm{i}}$

Where $\beta_{\mathrm{q}}$ is the vector of unknown parameters associated with the $\mathrm{q}^{\text {th }}$ quantile.

Quantile regression is considered to provide a more robust result to non-normal errors and outliers. By fitting linear regressions on different conditional quantiles of the range of a response variable (Koenker and Hallock, 2001, Hao et al., 2007), quantile regression allows a more complete statistical analysis of the stochastic relationships among random variables. Quantile regression also gives a more comprehensive characterization of the dataset, allowing us to estimate the influences of a covariate on the entire distribution, not merely its conditional mean.

Quantile regression has been used in a wide range of researches such as monetary policy and food inflation(Iddrisu and Alagidede, 2020), the effect of tourism on economic resilience (Cheng and Zhang, 2020), house prices and spatial distribution (Liao and Wang, 2012), housing attributes and real estate prices(Choy et al., 2012), the determinants of household embedded carbon emissions(Han et al., 2015).

In this case, the quantile regression is suitable for exploring how differently price-rent ratio at different quantiles responds to the impacts of built environmental influencing factors, rather than estimating the constant regression coefficient representing the change in the response variable produced by a one-unit change in the predictor variable associated with that coefficient. It estimates the implicit price-rent ratio for each characteristic across the distribution of the price-rent ratio. Moreover, it allows higher price-rent ratio properties have different behaviors compared to lower price-rent ratio properties, even if they are within the same housing estate. Thus, the quantile regression can provide a better 
explanation of the real-world cases and help us have a more comprehensive understanding of the relationship between price-rent ratio and built environment influencing factors.

\section{Result and discussion}

\subsection{Price-rent ratio distribution}

The research area was divided into cells by $500 \mathrm{~m} \times 500 \mathrm{~m}$. With IDW method in the geostatistical analysis module of ArcGIS software, we can determine the spatial interpolation of the housing price (Fig 4 , a) and housing rent (Fig 4, b) subsequently. Each cell's housing price and housing rent is the mean of all the points' values in the search area of the neighborhood (maximum 10 nearest points and minimum 5 nearest points). The result is showed in Figure 5.

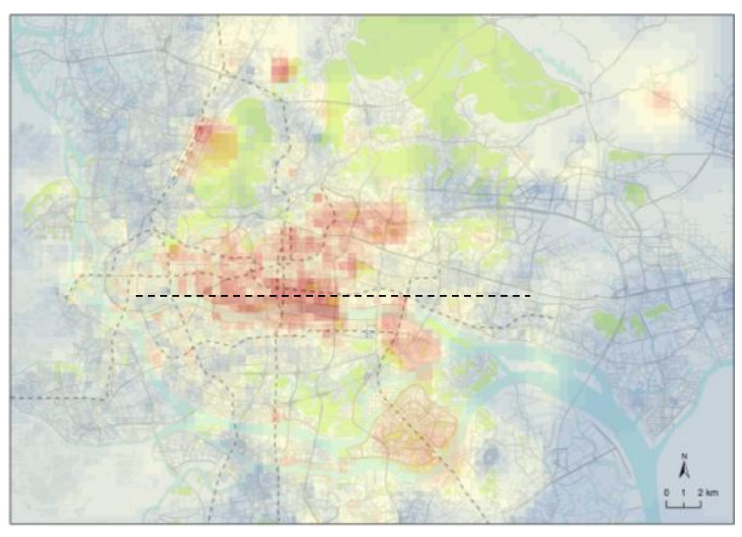

(a)

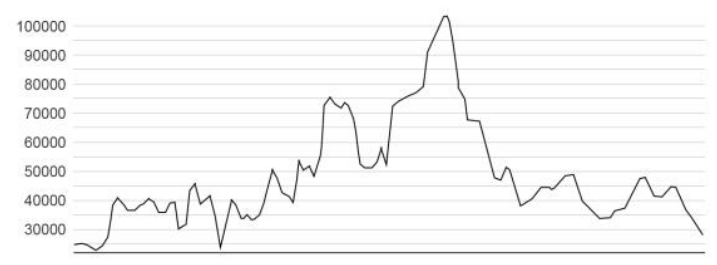

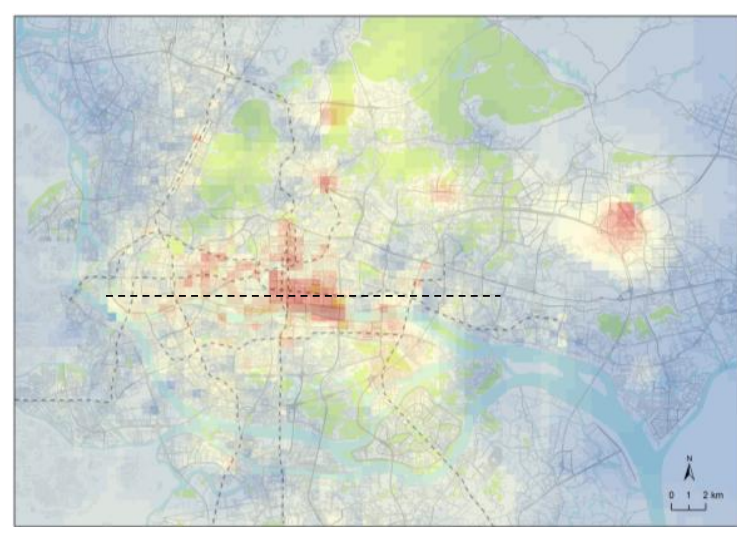

(b)

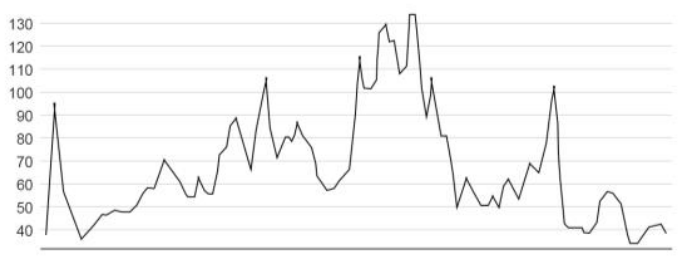

Figure 5. spatial distribution of housing price(a) and housing rent(b)

As can be seen, housing prices show a trend of decreasing from the center to the periphery. The highs lie in the downtown of the city, closed to the $C B D$, surrounded by numerous companies and financial institutions. Catering services and living services are nearby. The housing rents show a trend of uneven group distribution. The rents in the newly-built downtown and parts of the southwestern old built-up area are high. 


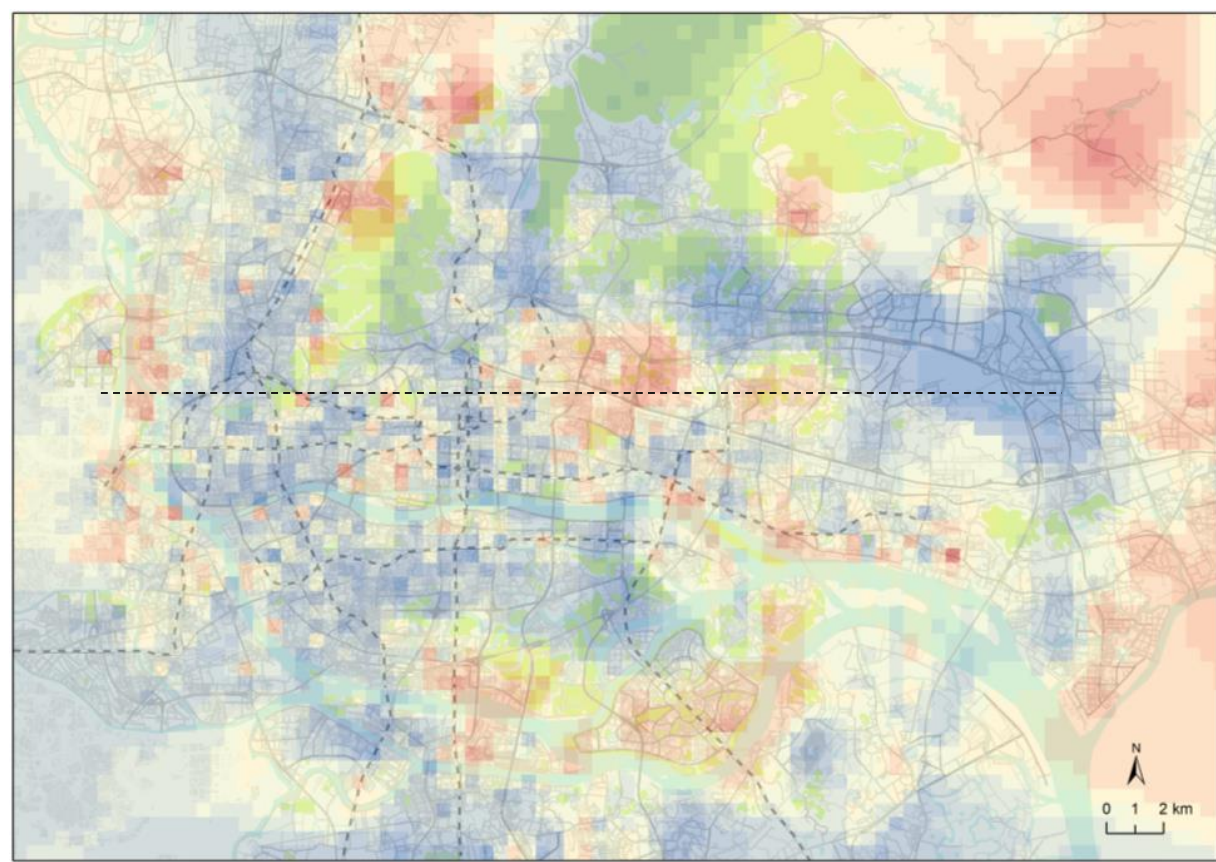

(a)

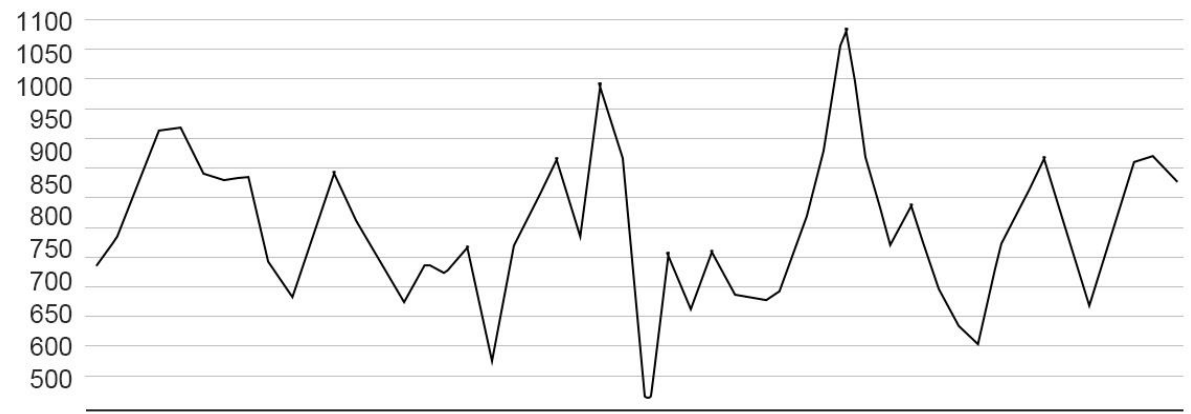

(b)

Figure 6. spatial distribution of price-rent ratio(a) and the cross-section of price-rent ratio (b)

By the price-rent ratio function mentioned in 4.3, the price-rent ratio was calculated and the spatial distribution of the price-rent ratio in Guangzhou is shown in Figure 6. The price-to-rent ratio shows the following spatial distribution pattern:

(1) The price-to-rent ratio generally shows a dispersed and group distribution with multiple centers. The highs and the lows are interleaved with each other, further presenting a disorder mottled distribution pattern of price-to-rent ratio.

(2) The lows lie in the downtown of the newly-built or old built-up area. The rental market is active in these areas and the price-rent ratio is reasonable. The highs lie in the suburbs or handed-over areas between newly-built and old built-up parts of the city. The peak of price-to-rent ratio not always locate in high housing price areas or low housing rent areas, they show a synergy effect.

\subsection{Quantile regression}

The central points of each $500 \mathrm{~m} \times 500 \mathrm{~m}$ cells are chosen as the sampling point of the price-rent ratio. We calculate the variables of each sampling point. The statistics results of sampling points are shown in Table.2. 
The Sustainable-based Impacts of Built Environmental Influencing Factors on Price-rent Ratio: A Case Study in Guangzhou

Table 2. Statistics description

\begin{tabular}{|c|c|c|c|c|c|c|c|c|c|c|}
\hline & $\min$ & $\max$ & range & median & mean & $\begin{array}{c}\text { standard } \\
\text { error } \\
\text { mean } \\
\end{array}$ & $\begin{array}{l}95 \% \text { mean } \\
\text { confidenc } \\
\text { e interval }\end{array}$ & variation & $\begin{array}{l}\text { standard } \\
\text { deviation }\end{array}$ & $\begin{array}{c}\text { Coefficient } \\
\text { of } \\
\text { variation }\end{array}$ \\
\hline price-rent ratio & 172.536 & 2100.97 & 1928.434 & 738.0435 & 750.5257 & 2.610131 & 5.116947 & 35617.23 & 188.7253 & 0.251457 \\
\hline catering & 0 & 268 & 268 & 1 & 10.21442 & 0.294138 & 0.576633 & 452.3116 & 21.26762 & 2.082117 \\
\hline Life service & 0 & 265 & 265 & 5 & 19.65264 & 0.486464 & 0.953674 & 1237.194 & 35.17376 & 1.789773 \\
\hline $\begin{array}{c}\text { Leisure \& } \\
\text { entertainment }\end{array}$ & 0 & 39 & 39 & 0 & 1.885425 & 0.054124 & 0.106105 & 15.31478 & 3.913411 & 2.075612 \\
\hline Sport facility & 0 & 36 & 36 & 0 & 0.510903 & 0.021982 & 0.043094 & 2.526187 & 1.589398 & 3.11096 \\
\hline shopping & 0 & 2538 & 2538 & 4 & 36.6863 & 1.401037 & 2.746617 & 10262.06 & 101.3018 & 2.761298 \\
\hline hospital & 0 & 19 & 19 & 0 & 0.912204 & 0.024495 & 0.048021 & 3.136924 & 1.771136 & 1.941602 \\
\hline university & 0 & 5 & 5 & 0 & 0.090857 & 0.005424 & 0.010633 & 0.153787 & 0.392156 & 4.316198 \\
\hline school & 0 & 18 & 18 & 0 & 1.152257 & 0.026132 & 0.051229 & 3.570079 & 1.889465 & 1.639795 \\
\hline Cultural facility & 0 & 18 & 18 & 0 & 0.444147 & 0.019449 & 0.038128 & 1.977557 & 1.406256 & 3.166197 \\
\hline Enterprise & 0 & 618 & 618 & 4 & 16.7588 & 0.652874 & 1.279906 & 2228.405 & 47.20598 & 2.816788 \\
\hline $\begin{array}{c}\text { financial } \\
\text { institution }\end{array}$ & 0 & 91 & 91 & 0 & 3.569816 & 0.1137 & 0.222899 & 67.5859 & 8.221065 & 2.302938 \\
\hline Government & 0 & 224 & 224 & 0 & 5.655891 & 0.188586 & 0.369707 & 185.9319 & 13.63568 & 2.410882 \\
\hline $\begin{array}{l}\text { Science \& culture } \\
\text { Institution }\end{array}$ & 0 & 51 & 51 & 0 & 0.911247 & 0.048476 & 0.095033 & 12.28521 & 3.505027 & 3.846407 \\
\hline industry park & 0 & 7 & 7 & 0 & 0.185539 & 0.007666 & 0.015029 & 0.307256 & 0.554307 & 2.987542 \\
\hline Green space & 0 & 8254.33 & 8254.33 & 1020.77 & 1563.293 & 22.17181 & 43.46601 & 2570027 & 1603.13 & 1.025483 \\
\hline Waterfront & 0.092659 & 4234.721 & 4234.628 & 540.477 & 768.0016 & 10.16521 & 19.92806 & 540217.2 & 734.9947 & 0.957022 \\
\hline bus & 0 & 19 & 19 & 2 & 2.78137 & 0.038948 & 0.076354 & 7.930573 & 2.816127 & 1.012497 \\
\hline subway & 0 & 3 & 3 & 0 & 0.066756 & 0.003776 & 0.007403 & 0.074556 & 0.273049 & 4.090254 \\
\hline Road length & 0 & 40933.67 & 40933.67 & 9610.298 & 9974.902 & 76.55432 & 150.0785 & 30639028 & 5535.253 & 0.554918 \\
\hline number of floors & 0 & 4928 & 4928 & 25.5 & 474.2007 & 10.51359 & 20.61103 & 577879.9 & 760.1841 & 1.603085 \\
\hline coverage area & 0 & 505150.5 & 505150.5 & 4641.38 & 79110.84 & 1531.875 & 3003.115 & $1.23 E+10$ & 110762.1 & 1.400087 \\
\hline building area & 0 & 4386727 & 4386727 & 16856.81 & 384055.7 & 8508.265 & 16679.75 & $3.78 \mathrm{E}+11$ & 615189.3 & 1.601823 \\
\hline tourist attraction & 0 & 23 & 23 & 0 & 0.53137 & 0.020346 & 0.039886 & 2.16412 & 1.471095 & 2.768497 \\
\hline
\end{tabular}

As the units of variables are different, we first need to normalize the variables. After normalization, we conducted the $0.25,0.5,0.75$ quantile regression respectively. The models are shown in Table 3, Table 4, Table 5.

Table 3. Estimation of price-rent ratio using the 0.25 quantile regression model

\begin{tabular}{|c|c|c|c|c|}
\hline & Coefficient Value & Std. Error & $\mathrm{t}$ value & $\operatorname{Pr}(>|t|)$ \\
\hline (Intercept) & -0.64052 & 0.01815 & -35.2897 & 0 \\
\hline catering & -0.02573 & 0.031807 & -0.80891 & 0.418602 \\
\hline Life service & 0.094149 & 0.039724 & 2.370084 & 0.01782 \\
\hline Leisure \& entertainment & -0.01033 & 0.023566 & -0.43819 & 0.661264 \\
\hline Sport facility & 0.039214 & 0.022087 & 1.775456 & 0.075881 \\
\hline Shopping & -0.09553 & 0.013952 & -6.84759 & $8.38 \mathrm{E}-12$ \\
\hline Hospital & -0.03723 & 0.014908 & -2.49752 & 0.012537 \\
\hline University & 0.016157 & 0.007972 & 2.026631 & 0.042751 \\
\hline school & -0.02948 & 0.020607 & -1.4307 & 0.152577 \\
\hline Cultural facility & 0.019767 & 0.022948 & 0.861369 & 0.389075 \\
\hline Enterprise & 0.002818 & 0.013365 & 0.21082 & 0.833036 \\
\hline financial institution & -0.01948 & 0.026044 & -0.74805 & 0.454462 \\
\hline government & 0.010033 & 0.028946 & 0.3466 & 0.728905 \\
\hline Science \& culture Institution & 0.003316 & 0.013948 & 0.237716 & 0.81211 \\
\hline industrial park & -0.01056 & 0.022545 & -0.46851 & 0.639438 \\
\hline Green space & -0.03061 & 0.017856 & -1.71443 & 0.08651 \\
\hline Waterfront & 0.043576 & 0.017165 & 2.538751 & 0.011154 \\
\hline bus & -0.07509 & 0.021417 & -3.50599 & 0.000459 \\
\hline Subway station & 0.00163 & 0.013791 & 0.118197 & 0.905916 \\
\hline Road length & 0.023049 & 0.016719 & 1.378634 & 0.168067 \\
\hline number of floors & -0.02237 & 0.031808 & -0.70315 & 0.481997 \\
\hline coverage area & 0.152076 & 0.026178 & 5.809255 & $6.65 \mathrm{E}-09$ \\
\hline building area & -0.08541 & 0.039674 & -2.15291 & 0.031372 \\
\hline tourist attraction & -0.01924 & 0.019275 & -0.99839 & 0.318137 \\
\hline
\end{tabular}


Table 4. Estimation of price-rent ratio using the 0.5 quantile regression model

\begin{tabular}{|c|c|c|c|c|}
\hline & Coefficient Value & Std. Error & $\mathrm{t}$ value & $\operatorname{Pr}(>|t|)$ \\
\hline (Intercept) & -0.05389 & 0.015704 & -3.43156 & 0.000605 \\
\hline catering & -0.01805 & 0.033703 & -0.53559 & 0.592262 \\
\hline Life service & 0.069855 & 0.041875 & 1.668165 & 0.095343 \\
\hline Leisure \& entertainment & -0.0857 & 0.025651 & -3.34102 & 0.000841 \\
\hline Sport facility & 0.037778 & 0.009053 & 4.172876 & $3.06 \mathrm{E}-05$ \\
\hline Shopping & -0.11033 & 0.023864 & -4.62322 & 3.87E-06 \\
\hline Hospital & -0.01279 & 0.021938 & -0.58305 & 0.559884 \\
\hline university & -0.03091 & 0.013922 & -2.22022 & 0.026447 \\
\hline school & -0.04822 & 0.021234 & -2.27066 & 0.023208 \\
\hline Cultural facility & 0.042332 & 0.021926 & 1.930656 & 0.05358 \\
\hline Enterprise & -0.02396 & 0.02016 & -1.18841 & 0.234726 \\
\hline financial institution & -0.02946 & 0.027694 & -1.06367 & 0.287529 \\
\hline government & 0.023544 & 0.029924 & 0.786798 & 0.431436 \\
\hline Science \& culture Institution & 0.053661 & 0.012908 & 4.157262 & 3.27E-05 \\
\hline industrial park & -0.00291 & 0.012667 & -0.22986 & 0.818207 \\
\hline Green space & 0.0665 & 0.01769 & 3.75896 & 0.000172 \\
\hline Waterfront & 0.045058 & 0.017007 & 2.649435 & 0.008087 \\
\hline bus & -0.0312 & 0.020327 & -1.53515 & 0.124807 \\
\hline Subway station & -0.0157 & 0.01509 & -1.04048 & 0.298166 \\
\hline Road length & 0.036281 & 0.018118 & 2.002449 & 0.045288 \\
\hline number of floors & 0.046823 & 0.04281 & 1.093736 & 0.274121 \\
\hline coverage area & 0.011556 & 0.031547 & 0.366293 & 0.714161 \\
\hline building area & -0.0247 & 0.047471 & -0.5204 & 0.602806 \\
\hline tourist attraction & -0.0506 & 0.013928 & -3.63291 & 0.000283 \\
\hline
\end{tabular}

Table 5. Estimation of price-rent ratio using the $\mathbf{0 . 7 5}$ quantile regression model

\begin{tabular}{|c|c|c|c|c|}
\hline & Value & Std. Error & $\mathrm{t}$ value & $\operatorname{Pr}(>|t|)$ \\
\hline (Intercept) & 0.557047 & 0.019881 & 28.01902 & 0 \\
\hline catering & -0.0043 & 0.040462 & -0.10626 & 0.915378 \\
\hline Life service & 0.03398 & 0.04064 & 0.836132 & 0.403119 \\
\hline Leisure \& entertainment & -0.07189 & 0.029495 & -2.43737 & 0.014828 \\
\hline Sport facility & 0.037239 & 0.019589 & 1.901042 & 0.057352 \\
\hline Shopping & -0.12002 & 0.038663 & -3.10436 & 0.001917 \\
\hline hospital & 0.005347 & 0.016987 & 0.31477 & 0.752949 \\
\hline university & -0.03384 & 0.018172 & -1.86196 & 0.062665 \\
\hline school & -0.06545 & 0.018849 & -3.47211 & 0.000521 \\
\hline Cultural facility & 0.043534 & 0.019258 & 2.260611 & 0.023824 \\
\hline Enterprise & -0.00252 & 0.029103 & -0.08672 & 0.9309 \\
\hline finance & 0.001089 & 0.037831 & 0.028792 & 0.977032 \\
\hline government & 0.036364 & 0.024751 & 1.469217 & 0.141834 \\
\hline Science \& culture Institution & 0.026466 & 0.024768 & 1.068566 & 0.285315 \\
\hline industrial park & -0.03084 & 0.016166 & -1.90794 & 0.056454 \\
\hline Green space & 0.013423 & 0.016619 & 0.807665 & 0.41932 \\
\hline Waterfront & 0.174238 & 0.023912 & 7.286537 & $3.66 \mathrm{E}-13$ \\
\hline bus & -0.02311 & 0.021946 & -1.05309 & 0.29235 \\
\hline Subway station & -0.0374 & 0.017925 & -2.08653 & 0.036979 \\
\hline Road length & 0.009348 & 0.016861 & 0.554389 & 0.579336 \\
\hline number of floors & -0.01217 & 0.04574 & -0.26608 & 0.790191 \\
\hline coverage area & 0.047992 & 0.035211 & 1.362986 & 0.172946 \\
\hline building area & -0.02315 & 0.050638 & -0.45721 & 0.647536 \\
\hline tourist attraction & -0.0666 & 0.015093 & -4.4128 & $1.04 \mathrm{E}-05$ \\
\hline
\end{tabular}

We conducted the Quandt Likelihood Ratio (QLR) Test to this model. As $p$ values of this model are smaller than 0.0001, the model passes the QLR test and proved to be effective. The smaller Akaike's Information Criteria (AIC) value means the model performs better. In this case, the 0.5 quantile model performs best. 
Table 6. Model evaluation

\begin{tabular}{|c|c|c|c|}
\hline & AIC & QLR & P value \\
\hline 0.25 quantile model & 69651.86 & 110.4676 & $4.67 \mathrm{E}-13$ \\
\hline 0.5 quantile model & 69343.59 & 159.7292 & 0 \\
\hline 0.75 quantile model & 70489.22 & 221.0565 & 0 \\
\hline
\end{tabular}

\subsection{Discussion}

In a quantile regression model, when $\mathrm{P}$ values of the variables are smaller than 0.05 , the influences of the corresponding variables are significant. The coefficient value represents the degree of influence. The larger the coefficient value is, the greater the influence of this variable will be.

In these three models, the price-to-rent ratios show the following characteristics:

The distance to the waterfront affects the price-rent ratio in all three quantiles. Water has a positive impact on the price-rent ratio. The closer to the waterfront, the lower the price-rent ratio will be. The lower price rent ratio reflects people's preferences for living near the waterfront. For example, people would prefer to rent houses to live nearby the waterfront even if they don't own houses nearby. If people own houses nearby the waterfront, they may prefer to use the house for personal residence rather than real estate speculation. This means that a good landscape view may contribute a reasonable price-rent ratio and promotes a balanced relationship between housing price and housing rent.

The impacts of shopping centers are significant in all three quantiles. The number of shopping centers has a negative impact on the price-rent ratio. The more shopping centers near a house, the lower the price-rent ratios will be. This means that easy to access shopping centers and commercial services will contribute to the balance of the price-rent ratio.

Education resources such as schools and universities contribute to all three quantiles. Universities' influences are more significant in lower quantile, while schools' influences are more significant in higher quantile. In the medium quantile and high quantile of price-rent ratio, the price-rent ratio decrease as the number of schools and universities increases, which reflected people's living preferences brought by education resources of the school. Driven by the school district system in China, people's pursuit of educational resources makes people eager to living near key schools, which has propelled the active if rental market.

Accessibility such as the number of bus stations or subway stations also has influences on the pricerent ratio. The number of bus stations and the number of bus stations has a negative impact on the pricerent ratio. The more bus station and subway stations nearby, the lower the price-rent ratio will be. The properties which have convenient transportation may promote the owners to live in rather than real estate speculation. This means that the construction of public transit will contribute to the balance of the price-rent ratio. Moreover, the Bus stations' influences are more significant in the lower quantile, while subway stations' influences are more significant in the higher quantile. This may because the area of low quantile mainly locate in the suburbs, where people rely on subways for daily commuting.

0.5 quantile regression reflects the effect of built environment factors on average-level price-rent ratio. In this quantile, leisure \& entertainment, sports facility, science \& culture Institution, green space, tourist attractions all have impacts on price-rent ratio. It is worth mentioning that green space shows a significant positive impact of the price-rent ratio. The closer to green space, the lower the price-rent ratio will be. The lower price rent ratio also reflects people's preferences for living near green spaces. The number of leisure $\&$ entertainment also promotes the decrease of the price-rent ratio. 0.25 quantile regression reflects the effect of built environment factors on the low-level price-rent ratio. In this 
quantile, life service, hospital, coverage area all have impacts on the price-rent ratio, among which the number of hospitals has a negative impact on the price-rent ratio. The more hospital near the house, the lower the price-rent ratio will be. 0.75 quantile regression reflects the effect of built environment factors on the high-level price-rent ratio. In this quantile, leisure \& entertainment, cultural facility, tourist attraction contribute to price-rent ratio, among which the number of leisure \& entertainment has a negative impact on price-rent ratio. The more leisure \& entertainment facilities near the house, the lower the price-rent ratio will be. By comparing these three models under different quantile, we can find that daily life services contribute more to low-level price-rent ratio and leisure, entertainment and cultural facility contributes more to the high-level price- rent ratio.

These results shed light on sustainable real estate development. Firstly, a pleasant environment and green infrastructure construction such as green space and waterfront will promote people's living preferences and decrease the real estate speculation, which will promote the decrease of price-rent ratio. Secondly, the construction of public transit will contribute to the balance of the price-rent ratio. Thirdly, convenient commercial services are important. The basic life services such as hospitals, as well as the spiritual services such as leisure and entertainment facilities and educational services such as school also promote the decrease of price-rent ratio. The former mainly contribute to the lower quantile of the price-rent ratio and the later main contributes to the higher quantile of the price-rent ratio.

\section{Conclusions}

The price-rent ratio is an indicator of the real estate market. The housing price-rent ratio and urban sustainability are mutually reinforcing. A reasonable housing price-rent ratio will promote the sustainable development of the real estate market, thereby promoting the sustainable development of the city. Sustainable urban construction will also promote the rationalization of the housing price-rent ratio in turn, which will have a positive impact on the real estate market. Exploring and comparing factors affecting the price-rent ratio is important for urban sustainability. This study conducted an analysis of the spatial distribution patterns and influencing factors of housing price-rent ratio in Guangzhou based on housing transactions and housing rent data in 2018 in Guangzhou. Firstly, we utilized Inverse distance weighted interpolation methods to estimate the price-rent ratio based on the housing sales data and housing rental data. Secondly, this study utilized the quantile regression model to extract the most influential factors. Finally, the study discussed the spatial distribution pattern of the price-rent ratio and the influencing mechanisms of urban sustainability construction and the price-rent ratio. The results show that the price-rent ratio of Guangzhou has a dispersed distribution pattern with multiple centers, which is different from the spatial distribution pattern of housing price and housing rent. The highs lie in the suburbs or handed-over areas between newly-built and old built-up parts of the city. Life services such as leisure and entertainment, shopping centers, sports facility, education resources such as universities and schools, green infrastructure such as green space and waterfront all influenced the pricerent ratio. Daily Life services contribute more to low-level price-rent ratio and leisure, entertainment and cultural facility contributes more to the high-level price- rent ratio. Sustainable urban development as well as real estate development should pay attention to the construction of green infrastructure, public transit, commercial services, medical service, spiritual services and educational services.

However, there are some limitations. First, while employed a large dataset and conducted a detailed analysis, this study should acknowledge that these results of the most influencing factors could be difficult to transfer to the numeric index of urban construction, such as greening rate, water coverage rate and the number of facilities per area. Further investigations are needed to translate these influencing factors into actionable real estate development guidelines to promote better sustainable urban development as well. Moreover, the data used in this study was scraped from the largest real estate brokerage platform. Although the quantity of real-world housing prices and housing rent data in 
this study is large, a part of the records is still missing in some urban areas, which may lead to a bias in IDW interpolation estimates. In addition, this study was limited to Guangzhou. The most influential factors extracted from the quantile regression model may be examined in the price-rent ratio data in other cities for more comprehensive analysis in the future.

\section{References}

ABEDINI, A., EBRAHIMKHANI, H. \& ABEDINI, B. 2016. Mixed method approach to delineation of functional urban regions: Shiraz Metropolitan Region. Journal of Urban Planning and Development, 142, 04016001.

ANSELIN, L. \& LE GALLO, J. 2006. Interpolation of air quality measures in hedonic house price models: spatial aspects. Spatial Economic Analysis, 1, 31-52.

CHENG, L. \& ZHANG, J. 2020. Is tourism development a catalyst of economic recovery following natural disaster? An analysis of economic resilience and spatial variability. Current Issues in Tourism, 1-22.

CHOY, L. H., HO, W. K. \& MAK, S. W. 2012. Housing attributes and Hong Kong real estate prices: a quantile regression analysis. Construction Management and Economics, 30, 359-366.

COHEN, J. P. \& COUGHLIN, C. C. 2008. Spatial hedonic models of airport noise, proximity, and housing prices. Journal of regional science, 48, 859-878.

CRONIN, D. \& MCQUINN, K. 2016. Credit availability, macroprudential regulations and the house price-to-rent ratio. Journal of Policy Modeling, 38, 971-984.

DIACONU, D. C., BRETCAN, P., PEPTENATU, D., TANISLAV, D. \& MAILAT, E. 2019. The importance of the number of points, transect location and interpolation techniques in the analysis of bathymetric measurements. Journal of Hydrology, 570, 774-785.

HAN, L., XU, X. \& HAN, L. 2015. Applying quantile regression and Shapley decomposition to analyzing the determinants of household embedded carbon emissions: evidence from urban China. Journal of Cleaner Production, 103, 219-230.

HAO, L., NAIMAN, D. Q. \& NAIMAN, D. Q. 2007. Quantile regression, Sage.

HUI, E. C., CHAU, C., PUN, L. \& LAW, M. 2007. Measuring the neighboring and environmental effects on residential property value: Using spatial weighting matrix. Building and environment, 42, 2333-2343.

IDDRISU, A.-A. \& ALAGIDEDE, I. P. 2020. Monetary policy and food inflation in South Africa: A quantile regression analysis. Food Policy, 101816.

JIBOYE, A. D. 2011. Achieving sustainable housing development in Nigeria: A critical challenge to governance. International journal of humanities and social science, 1, 121-127.

JUNMING, S. J. L. 2007. A study on interpolation techniques in the Digital Model- - the case of Shanghai inner belt-way district [J]. China Civil Engineering Journal, 1.

KISHOR, N. K. \& MORLEY, J. 2015. What factors drive the price-rent ratio for the housing market? A modified present-value analysis. Journal of Economic Dynamics and Control, 58, 235-249.

KOENKER, R. \& HALLOCK, K. F. 2001. Quantile regression. Journal of economic perspectives, 15, 143-156.

LEE, J. S. \& LI, M.-H. 2009. The impact of detention basin design on residential property value: Case studies using GIS in the hedonic price modeling. Landscape and Urban Planning, 89, 7-16.

LI, S., YE, X., LEE, J., GONG, J. \& QIN, C. 2017. Spatiotemporal analysis of housing prices in China: A big data perspective. Applied Spatial Analysis and Policy, 10, 421-433.

LIAO, W.-C. \& WANG, X. 2012. Hedonic house prices and spatial quantile regression. Journal of Housing Economics, 21, 16-27.

LIU, T., OPALUCH, J. J. \& UCHIDA, E. 2017. The impact of water quality in Narragansett Bay on housing prices. Water Resources Research, 53, 6454-6471.

NAKAGAWA, M., SAITO, M. \& YAMAGA, H. 2007. Earthquake risk and housing rents: evidence from the Tokyo Metropolitan Area. Regional Science and Urban Economics, 37, 87-99.

SOMMER, K., SULLIVAN, P. \& VERBRUGGE, R. 2010. Run-up in the house price-rent ratio: how much can be explained by fundamentals?, US Department of Labor, Bureau of Labor Statistics, Office of Prices and ....

VISSER, P., VAN DAM, F. \& HOOIMEIJER, P. 2008. Residential environment and spatial variation in house prices in the Netherlands. Tijdschrift voor economische en sociale geografie, 99, 348-360. 
XIE, Y. \& LIU, H. 2004. Price-rent ratio in china's housing market: Proper interval, measurement and an empirical study. International Journal of Strategic Property Management, 8, 73-86.

YANG, L., WANG, B., ZHOU, J. \& WANG, X. 2018. Walking accessibility and property prices. Transportation research part $D$ : transport and environment, 62, 551-562.

YU, D., WEI, Y. D. \& WU, C. 2007. Modeling spatial dimensions of housing prices in Milwaukee, WI. Environment and Planning B: Planning and Design, 34, 1085-1102.

ZHAI, D., SHANG, Y., WEN, H. \& YE, J. 2018. Housing price, housing rent, and rent-price ratio: Evidence from 30 cities in China. Journal of Urban Planning and Development, 144, 04017026. 